Review article

\title{
HORMONES IN FOOD AS A POTENTIAL RISK FOR HUMAN REPRODUCTIVE AND HEALTH DISORDERS
}

\author{
SNOJ Tomaž* \\ University of Ljubljana, Veterinary Faculty, Institute of Preclinical Sciences, Gerbičeva 60, \\ 1000 Ljubljana, Slovenia
}

(Received 20 May, Accepted 28 May 2019)

In the last 60 years, milk, meat, and egg worldwide consumption per capita increased 2-, 3 -, and 5-fold, respectively. In the same period, several studies have reported a drop of semen quality and an increased incidence of cryptorchidism, hypospadias, and some hormone-related cancers (testicular, prostate, breast, endometrial cancer) in humans. A possible reason for these disruptions is increased exposure to exogenous hormones in food of animal origin. Hormones in food are considered to affect the endocrine system and cell signaling and thus disrupt homeostasis in the consumers. Since food safety assurance is a part of the veterinary service, the risk assessment of hormones in food as potential disruptive compounds is a significant challenge. Numerous cohort and epidemiologic studies and meta-analyses have been performed with respect to find an association between the consumption of food of animal origin and particular health disorders. Additionally, several studies in animal models have been performed to explain the mechanisms of disruptive effects of exogenous hormones. Since contradictory results have been reported, there is no general conclusion about the disruptive effects of exogenous hormones. Further experiments on animals in which long-term treatment with exogenous hormones is performed and further comprehensive endocrinological, toxicological, and human epidemiological studies are needed to confirm or deny the role of exogenous hormones in human health disorders. Moreover, long-term exposure to a combination of several exogenous compounds, such as environmental pollutants and dietary hormones and their additive effects, are also not well known and should be a topic for further studies.

Key words: food of animal origin, hormones, estrogens, health disorders

\section{INTRODUCTION}

Since the 1960s, meat production across the world has grown 5 to 6 fold. Similarly, milk production has increased almost 3 fold and hens egg production 4 fold. Additionally, freshwater and marine fish production and industry fishing has increased 5 fold [1]. Production of food of animal origin increased sharply and disproportionately to the human population. Therefore, the consumption of food of animal origin has

\footnotetext{
*Corresponding author: e-mail: tomaz.snoj@vf.uni-lj.si
} 
been steadily increasing in the recent decades. Statistical data show the dramatically increased consumption of food of animal origin per capita. Current consumption of food of animal origin in some countries is shown in Table 1. According to the FAO report [2], in the last 60 years, milk, meat, and egg consumption increased 2-, 3-, and 5 -fold, respectively.

Table 1. Per capita annual consumption of food of animal origin in 2013

\begin{tabular}{lcccc}
\hline & Meat $\mathbf{( k g )}$ & Milk $\mathbf{( k g )}$ & Eggs $\mathbf{( k g )}$ & Seafood $\mathbf{( k g )}$ \\
\hline Australia & 116.23 & 234.49 & 8.51 & 26.09 \\
Brazil & 97.58 & 149.28 & 8.98 & 10.87 \\
China & 61.82 & 33.18 & 18.65 & 34.67 \\
Egypt & 30.47 & 59.46 & 4.59 & 22.12 \\
India & 3.69 & 84.50 & 2.58 & 5.04 \\
Russia & 74.82 & 163.57 & 15.43 & 22.93 \\
Serbia & 53.32 & 148.53 & 8.89 & 5.80 \\
Sweden & 81.57 & 341.23 & 13.37 & 32.01 \\
USA & 115.13 & 254.69 & 14.58 & 22.51 \\
\hline
\end{tabular}

Data are adapted from Ritchie and Roser [1].

In the same period, a decrease of semen quality was observed, and an increased incidence of cryptorchidism, hypospadias, and some hormone-related cancers (testicular, prostate, breast, endometrial cancer) were reported by several studies [3-7]. The etiology of these disorders is not completely clear, although exposure to different chemicals with hormonal activity or even estrogens themselves have been proposed to contribute to these disorders. As described by Sharpe and Skakkabeak [8], in addition to some environmental pollutants, residues of contraceptives, mycoestrogens, and phytoestrogens, food of animal origin is a significant source of exogenous hormones. Food of animal origin contains relatively high amounts of androgens, estrogens, progestogens, and glucocorticoids. Thus, the modern western diet is a source of considerable amounts of exogenous hormones [7,8].

Since the veterinary profession is responsible for food safety assurance, the impact of hormones in food on human health is an important topic of research and debate. Courant et al. [9] suggested that risk assessment studies of steroid endocrine disruptors are necessary to evaluate their disruptive activity. However, the determination of the maximum residue limits (MRLs) for natural hormones in food presents a challenge for competent authorities, since there is a wide range of average daily intake of food of animal origin among individuals. In the EU, the process of determination of MRLs for natural hormones in food has not started yet. Furthermore, although there is a broad consensus of the importance of this problematic area the regulatory 
definition of endocrine disruption is not agreed upon [10]. Some of the recommended values for hormones in foodstuff were established by the EU reference laboratory for residua [11], predominantly due to control of the use of prohibited hormonal growth promoters (Table 2). Additionally, according to the FDA guidelines [12], no physiological effects of estrogens are expected to occur when consumption is less than $1 \%$ of endogenous quantities produced by the segment of the population with the lowest daily production - prepubertal boys. Thus, as suggested by Macrina et al. [13], no health-harming effect is to be expected if the daily intake of estrogens is less than $540 \mathrm{ng} /$ day.

Table 2. Recommended levels of $17 \beta$-estradiol and testosterone in meat-producing animals

\begin{tabular}{llc}
\hline & Serum $(\mathbf{n g} / \mathbf{m L})$ & Muscle $(\mathbf{n g} / \mathbf{g})$ \\
\hline $17 \beta$-estradiol & 0.1 & 1.0 \\
Testosterone & Male $<6$ months: 10 & \\
& Male $6-18$ months: 30 & \\
& Female $<18$ months: 0.5 & \\
\hline
\end{tabular}

Data are adapted from CRL guidance paper [11]

The effect of hormones in food on human health most likely depends on several factors: the susceptibility of individuals (age, sex, pregnancy, and individual characteristics), the quantity of intake, and on the concentration of hormones in food. Since food of animal origin is widely available, and the choice of nutrition is a personal decision, the quantity of intake varies among individuals. Since MRLs for hormones in food are not established, professional guidelines backed by scientific facts about the acceptable amounts of hormones in food would be appreciated.

In this review, the role of exogenous hormones in hormonal disruption, the presence of hormones in food of animal origin and the impact of exogenous hormones on reproductive and health issues are described.

\section{THE IMPACT OF EXOGENOUS HORMONES ON ENDOCRINE HOMEOSTASIS}

Steroid hormones bind to the specific intracellular receptors forming a steroid-receptor complex that enters the cell nucleus and stimulates (or inhibits) the transcription of genes and also promotes cell proliferation. Some exogenous compounds with hormonal activity can also bind to steroid receptors. They act as agonists or antagonists of different hormonal receptors or influence the activity of some enzymes that are involved in steroidogenesis (e.g., aromatase) and thus disrupt cell signaling and homeostasis $[8,14,15]$. In addition, steroid hormones are involved in the feedback loops that control the secretion of releasing hormones in the hypothalamus: testosterone, progesterone and $17 \beta$-estradiol control GnRH production and consequent FSH and LH secretion, cortisol influences ACTH production, etc. Synthesis of hormones is precisely regulated, and even small disturbances in this process can influence the 
endocrine homeostasis. Exogenous estrogens can disrupt the hypothalamic-pituitarygonadal (HPG) axis; they can interfere with the normal function of estrogen receptors in the hypothalamus and pituitary gland and in the peripheral estrogen-responsive tissues [16].

Several studies suggest that some reproductive, developmental, neurologic, oncologic, cognitive, and behavioral disorders in humans could be associated with the exposure to such endocrine disruptors $[17,18]$. It is assumed that in addition to lifestyle, exogenous compounds with the hormonal (mostly estrogenic) activity present in food and water might be associated with these disorders. Environmental pollutants with estrogenic activity (some pesticides, bisphenols, phthalates, PCBs, etc.) and hormones in the food of animal origin are most likely involved in endocrine disruption. Due to their strong biological activity and presence in several types of food of animal origin, estrogens are the most important agents in hormonal disruption. Potential exposure to exogenous estrogens is especially significant in regard to the prenatal and prepubertal development of the reproductive system in children. In some stages of development, androgen activity is necessary to provide sexual differentiation, the descent of the testes, brain development, and the onset of puberty [8]. These processes are precisely controlled by the HPG axis. Exogenous compounds with hormonal, especially estrogen activity, might influence and disrupt these developmental processes. Since the endogenous levels of estrogens in children are low, even small amounts of exogenous estrogens could interact with their hormonal system and disrupt the development of the urogenital tract, mammary glands, and the central nervous system [8,17-19]. Some of these disruptions could become evident only in adult life, even though they originate in prenatal or early postnatal disturbances of hormonal balance. Although the FDA suggests that no effects of exogenous hormones occur if daily intake is lower than $1 \%$ of daily individual production [12], it is still not clear how a combination of different hormones, their precursors and metabolites, and prolonged exposure to relatively low doses influence the body. It must be taken into account that, in some individuals, milk and meat products or a combination of both are consumed daily for years.

Many types of cells, such as glandular mammary cells, ovary, uteri, and cervical cells, can respond to estrogen stimulation with differentiation and proliferation. Although relatively low doses of exogenous hormones enter the body by food, constant exposure to these compounds might result in the differentiation and proliferation of some cells and can induce cancer development. In addition to estrogens, androgens and IGF-1 express proliferative activity [20,21].

\section{HORMONES IN FOOD OF ANIMAL ORIGIN}

Every foodstuff that contains components of animal origin (except honey) contains residua of steroid hormones (Table 3). These steroids were synthesized in steroidogenic tissues of the animals from which food was produced. Since steroids are highly fat-soluble, they are accumulated in tissues with high fat content. Additionally, 
steroid hormones are resistant to high temperature, and thermal treatment minimally decreases steroid hormone concentration in foodstuffs $[22,23]$.

Table 3. Concentration of steroid hormones in animal tissues and products

\begin{tabular}{|c|c|c|c|c|}
\hline & $\begin{array}{l}\text { Estrogens: up to } \\
\text { (ng/g or } \mathrm{ng} / \mathrm{mL})\end{array}$ & $\begin{array}{l}\text { Progestogens: up to } \\
\text { (ng/g or ng/mL) }\end{array}$ & $\begin{array}{l}\text { Androgens: up to } \\
\text { (ng/g or } \mathrm{ng} / \mathrm{mL} \text { ) }\end{array}$ & References \\
\hline Bovine muscle & $\begin{array}{l}\text { E1: } 0.7 \\
\text { E2: } 0.9\end{array}$ & P4: 20.0 & $\begin{array}{c}\text { T: } 0.78 \\
\text { A: } 0.14 \\
\text { DHEA: } 0.30\end{array}$ & {$[9,24]$} \\
\hline Bovine liver & $\begin{array}{l}\text { E1: } 0.3 \\
\text { E2: } 1.4\end{array}$ & P4: 1.50 & $\begin{array}{l}\text { T: } 0.75 \\
\text { A: } 1.04\end{array}$ & {$[9,24]$} \\
\hline Bovine fat & $\begin{array}{l}\text { E1: } 5.4 \\
\text { E2: } 0.2\end{array}$ & P4: 4.55 & $\begin{array}{l}\text { T: } 10.95 \\
\text { A: } 10.31\end{array}$ & [24] \\
\hline Bovine kidney & E2: 0.04 & & $\begin{array}{c}\text { T: } 1.49 \\
\text { A: } 0.50 \\
\text { DHEA: } 0.88\end{array}$ & [9] \\
\hline Porcine muscle & $\begin{array}{l}\text { E1: } 0.16 \\
\text { E2: } 0.2\end{array}$ & P4: 1.76 & T: 0.23 & [24] \\
\hline Porcine liver & $\begin{array}{l}\text { E1: } 0.44 \\
\text { E2: } 0.32\end{array}$ & P4: 1.85 & T: 0.14 & [24] \\
\hline Porcine fat & $\begin{array}{l}\text { E1: } 0.20 \\
\text { E2: } 0.12\end{array}$ & & T: 0.32 & [24] \\
\hline Whole milk & $\begin{array}{l}\text { E1: } 0.15 \\
\text { E2: } 0.034\end{array}$ & P4: 12.5 & $\begin{array}{l}\text { T: } 0.12 \\
\text { A: } 3.5\end{array}$ & [24-26] \\
\hline $\begin{array}{l}\text { Milk of } \\
\text { pregnant cows }\end{array}$ & $\begin{array}{c}\text { E1: } 0.118 \\
\text { E1-sulphate: } 1.0 \\
\text { E2: } 0.005\end{array}$ & & & [27-29] \\
\hline $\begin{array}{l}\text { Commercial } \\
\text { milk }\end{array}$ & $\begin{array}{l}\text { E1: } 0.014 \\
\text { E2: } 0.005\end{array}$ & & & {$[30]$} \\
\hline Butter & $\begin{array}{c}\text { E1: } 1.47 \\
\text { E2: }<0.03\end{array}$ & $\begin{array}{l}\text { P4: } 141 \\
\text { Pre: } 50\end{array}$ & $\begin{array}{c}\text { T: }<0.05 \\
\text { A: } 5.98\end{array}$ & [24] \\
\hline Eggs & $\begin{array}{l}\text { E1: } 0.93 \\
\text { E2: } 0.36\end{array}$ & $\begin{array}{l}\text { P4: } 43.6 \\
\text { Pre: } 143\end{array}$ & $\begin{array}{c}\text { T: } 0.49 \\
\text { A: } 9.27 \\
\text { DHEA: } 0.34\end{array}$ & {$[9,24]$} \\
\hline Fish (herring) & $\begin{array}{c}\text { E1: } 0.02 \\
\text { E2: }<0.03\end{array}$ & $\begin{array}{l}\text { P4: } 0.51 \\
\text { Pre: } 1.0\end{array}$ & $\begin{array}{l}\text { T: } 0.07 \\
\text { A: } 0.29\end{array}$ & [24] \\
\hline
\end{tabular}

Legend: A - androstenedione; DHEA - dehydroepiandrosterone; E1 - estrone; E2 - 17 $\beta$-estradiol; P4 - progesterone; Pre - pregnenolone; T - testosterone

In farm animals, highest amounts of hormones were found in boar's tissues (testosterone: 20.34, E1: 6.59, E2: $16.90 \mathrm{ng} / \mathrm{g}$ ) [24]; however, this is not important for human health since boars' meat is not intended for human consumption.

Additionally, food of animal origin contains steroid precursors and metabolites that exhibit hormonal activity or might be reactivated during digestion. As an example: 
estrone sulphate, the main estrogen metabolite in milk, can be cleaved by endogenous and bacterial sulphatases during digestion and thus free biologically active estrone is formed [31,32].

Concentrations of each steroid hormone in food depend on animal species, age, sex, and reproductive and metabolic status; thus, there are significant differences between species and categories of animals. Fish contain fewer hormones than the meat of mammals, and veal contains fewer estrogens and testosterone than beef. Additionally, the concentration of estrogens is significantly higher in the milk of pregnant cows than in the milk of non-pregnant cows [24,28]. Moreover, the concentration of milk estrogens increases with the stage of pregnancy and is the highest in the third trimester of pregnancy [29]. As suggested by Ganmaa and Sato [7], the milk nowadays is very much different than it was 100 years ago. Nowadays, standard lactation in dairy cows is 305 days, and at the end of lactation cows are in late pregnancy, some of them are pregnant even more than eight months. During that period, the production of estrogens by the placenta is on a high level; consequently, milk contains a high concentration of estrogens. In contrast, 100 years ago, the majority of cows were milked only 4 or 5 months after parturition, and at the time they were in an early stage of pregnancy or even not pregnant. It cannot be established how much estrogens milk contained 100 year ago, but, due to shorter lactation, the concentration of the estrogens in milk was most likely lower than nowadays.

In some countries, such as USA, Canada, South Korea, Japan and Australia, use of hormonal growth promoters in beef production is a common practice that provides intensive weight gain in beef cattle and decreases the costs of meat production. Several steroidal (trenbolone, testosterone, $17 \beta$-estradiol, progesterone, medroxyprogesterone) and non-steroidal (zeranol) compounds are used for this purpose [33]. Meat produced in such practices might be a source of residua of synthetic compounds with hormonal activity. It was established that the meat of animals that were treated with $17 \beta$-estradiol contains a higher concentration of this hormone. Daily intake of such meat (in combination with other foodstuffs) might lead to the exposure to estrogens in amounts that exceed doses recommended by the FDA $[9,12]$. Even though there are no scientific conclusions about the harmful effects of such meat, most countries have prohibited the use of hormonal growth promoters due to food safety assurance.

Additionally, in the USA, recombinant bovine somatotropin (rbST) is used to enhance milk production. As rbST is a peptide hormone, its residua in food cannot be a risk for human health, since peptides are digested in the human gastrointestinal tract [34]. However, the use of rBST in dairy cows is questionable from the ethic point of view. Enhanced milk production causes several health disorders in cows, such as clinical and subclinical mastitis, lameness, ketosis, and hypocalcaemia. Furthermore, the longevity of rBST-treated cows is significantly reduced [35]. 


\section{HORMONES IN FOOD OF ANIMAL ORIGIN AND CONSUMERS' HEALTH}

Since the early 1990s, when hormones in food were presented as a possible reason for several health disorders, numerous epidemiological studies and meta-analyses have been performed to explain the role of exogenous hormones in this issue. In this review, some of these studies are referenced. In several studies, a correlation between the intake of the food of animal origin and the incidence of some reproductive and health issues are reported. Thus, the connection between red meat intake and reduced semen motility was reported; however, shellfish consumption has the opposite effect [36]. In the study by Afeiche et al. [37], semen of 189 donors from the US were analyzed in regard to the quality of consumed meat. Results showed reduced ejaculate volume and lower total sperm output in men who consumed meat, which originated from animals treated with growth promotors in comparison to men who consume organic meat. Since abstinence before semen collection was not considered, the authors concluded that further studies are necessary to clarify this issue.

Moreover, processed meat intake was negatively associated with fertilization rates among couples undergoing conventional IVF [38]. Additionally, dietary habits during pregnancy can influence the semen production capacity of sons. Thus, beef consumption (seven meals per week) affects testes development in the fetus, which is reflected in lower sperm production in adulthood [39]. Since the research was performed in the US, where growth promoters are in use, results cannot be applied to all kind of beef.

Milk and dairy products consumption was also studied with respect to semen quality. As reported by Afeiche et al. [40], low-fat milk intake is related to a higher sperm concentration and progressive motility. Full-fat milk and cheese consumption is associated with lower sperm motility, especially in smokers. However, another study from the same research group showed lower sperm progressive motility in men who consumed full-fat dairy products [41]. Similarly, Dizavi et al. [42] reported no or even a protective effect of low-fat dairy product intake on semen quality parameters, while a high intake of full-fat dairy products, full-fat milk, and ice cream exhibits a risk for oligospermia. It is known that full-fat dairy products contain relatively high amounts of steroid hormones and xenobiotics, both of which can affect hormonal homeostasis; therefore, a stronger effect of full-fat dairy products was somewhat expected. However, all the mentioned studies left opened questions about the direct role of hormones in milk on sperm production capacity. In contrast, Xia et al. [43] found no correlations between dairy intake and fertility in men.

Even though a decline of semen quality was reported by several studies, it cannot be concluded that the increased consumption of meat, milk, and dairy products in recent decades is a reason for this phenomena.

Hormones in the food of animal origin, especially $17 \beta$-estradiol and testosterone, can be considered as potential risk factors for cancer development. Several cancers are closely related to the endocrine system. Some cancers affect endocrine glands such as 
the adrenals, testes, and ovaries. Additionally, some cancerous cells are responsive to hormone stimulation. The development of breast, ovarian, and endometrial cancers is stimulated by estrogens, and prostate cancer is stimulated by testosterone. This has raised a concern about possible negative effects of the consumption of food of animal origin on the development or progression of such cancers.

Ganmaa and Sato [7] compared the intake of food of animal origin and the incidence of breast, ovarian, and corpus uteri cancer in 40 countries. In comparison to the developing countries, in the developed countries, with a higher average daily intake of meat and milk (and dairy products), a higher incidence of breast and uteri cancer was recorded. As mentioned by authors, it cannot be concluded that the western diet causes more risk for cancer, since data from developing countries are incomplete due to local medical and economic circumstances. A cohort study by Cross et al. [44] performed on 500,000 men and women, showed an association between red meat and processed milk consumption and colorectal and lung cancer. Red meat consumption was also correlated with the incidence of esophageal and liver cancer. Lung, liver, esophageal, and colorectal cancers are not hormone-related cancers; thus, the occurrence of these cancers cannot be associated with hormones in meat. Meat, other animal tissues, and mainly processed meat contain not only hormones, but also other potentially carcinogenic compounds, such as $\mathrm{N}$-nitroso compounds, which are metabolized into the highly carcinogenic nitrosoamides, and polycyclic aromatic hydrocarbons $[45,46]$. In contrast, some other studies did not find significant correlations between meat consumption and prostatic or endometrial cancer risk $[47,48]$.

Due to significant correlations between meat consumption and the incidence of colorectal cancer, WHO classified red meat into Group 2A, as probably carcinogenic to humans [49].

Several studies compare milk and dairy products consumption with cancer incidence. Ganmaa and Sato [7] found a higher rate of breast, ovarian, and uteri cancer in countries with high milk consumption. A meta-analysis by Dong et al. [50] suggests that intake of low-fat milk reduces the risk for breast cancer development. In the same study, high-fat milk was not observed as being protective. Similarly, Zang et al. [51], reported reduced risk for breast cancer in connection with low-fat dairy products consumption, while high-fat dairy products consumption does not influence the rate of breast cancer occurrence. Thus, it is possible that some milk ingredients inhibit the development of breast cancer, but estrogens inhibit this mechanism. In contrast, Moorman and Terry [52] found no correlation between the consumption of dairy products and epidemiological data on breast cancer. Similarly, an analysis of eight cohort studies by Missmer et al. [53] showed no correlation between milk consumption and the risk for breast cancer.

Furthermore, increased risk for prostatic and testicular cancer was reported in men who consumed higher quantities of dairy products in adolescence $[19,54]$. In contrast, no correlation was found between consumption of dairy products in adult 
life and prostatic cancer risk [19]. Aune et al. [55] also found an increased risk for prostate cancer in men with a high daily intake of dairy products. Contrary to these assumptions, Andersson et al. [56] did not find an association between the diet during childhood and risk for prostatic cancer. Therefore, the question about the role of sex steroid hormones in milk in the development of prostate and testicular cancer in humans remains open. Additionally, high egg consumption is also associated with the occurrence of several cancers, including breast and prostate cancer [57], while there is no correlation between the consumption of up to one egg per day and any cause of mortality [58]. Although preventing cardiovascular disorders, a diet high in fish increases the risk of ovarian and endometrial cancer [59].

There are only a few studies on animal models about the impact of meat consumption on health, none of which deals with disruptive effects of meat hormones. Santarelli et al. [60] treated experimental rats with different types of processed meat and found some markers of colorectal cancer in treated animals. Pernaud et al. [61] reported that beef consumption does not stimulate and poultry does not protect laboratory rats from colon cancer development. Also, studies on animal models that deal with the impact of hormones in milk on health disorders are contradictory. Zhou et al. [25] and Ganmaa et al. [62] reported uterotrophic effects of milk feeding in ovariectomized immature rats.

In contrast to the studies mentioned above, Li et al. [63] performed an experiment on a group of Wistar rats, fed with commercial milk. Reproductive parameters (fertility index, gestation index, weights of uterus and ovary, days of vaginal opening and length of the estrus cycle), histological parameters and IGF-1 blood levels did not differ from the control group.

Similarly, a comprehensive two-generations reproductive study on milk consumption in rats by Ganmaa et al. [64] in which rats were fed milk throughout two generations, showed no effect on reproduction. Our recent study showed the uterotrophic effect of milk with added estrogens, which exceed physiological concentrations 1,000 times [65]. In addition, an experiment performed by Qin et al. [66] showed an increased incidence of 7,12-dimethylbenz(A)anthracene induced mammary tumors in rats that received low-fat milk. Similarly, the consumption of low-fat milk increased mammary tumor incidence, probably due to exposure to water-soluble estrone sulphate, which is present in low-fat milk [66].

It is not clear if rodents respond to dietary hormones similarly to humans. The response depends on the intensity of intestinal absorption, first liver passage, the binding of absorbed hormones to sex-hormone-binding globulin (SHBG) or other carriers, the number of intracellular steroid receptors and species-specific cellular response to receptor-hormone stimulation, and mechanisms of inactivation, metabolism, and excretion. There is no exact data in the literature that would explain inter-species differences in response to exposure to exogenous hormones. Additionally, in animal studies, the exposure to hormones lasts a few weeks or months, whereas a human 
is exposed to exogenous dietary hormones throughout his or her life. These are the main shortcomings of animal studies on this topic. Thus, it can be assumed that the results of animal studies cannot apply directly to humans. However, animal models are useful for studying the kinetic and mechanistic properties of exogenous hormones and for the prediction of their disruptive effects in humans. Long-term exposure of humans to a combination of several exogenous compounds, such as environmental pollutants and dietary hormones, and their additive effects are not well known and should be a topic for further studies. Also, further experiments in animals in which long-term treatment with exogenous hormones and comprehensive endocrinological, toxicological, and human epidemiological studies are needed to confirm or deny the role of exogenous hormones in human health disorders.

Additional summarized data about the impact of hormones in food on human health are available in comprehensive reviews by Genkinger and Koushik [67], Panth et al. [68], Moorman and Terry [52], Missmer et al. [53], Davoodi et al. [69], Snoj and Majdič [70], Parodi [32], Malekinejad and Rezabakhsh [71], Keum et al. [72], and Snoj et al. [73] .

\section{CONCLUSIONS}

Although the consumption of food of animal origin and some reproductive and health disorders in humans dramatically increased in last decades, it cannot be concluded that exposure to relatively high amounts of exogenous hormones is a reason for these disorders. Studies dealing with these topics showed contradictory results, and thus no general conclusion can be applied. Further endocrinological and toxicological studies using animal models and human epidemiologic studies are necessary to explain the role of exogenous hormones in human health disorders.

\section{Acknowledgments}

The work was financially supported by Slovenian Research Agency, Grant No. P40053. English editing was performed by Terry Troy Jackson.

\section{Authors' contributions}

TS designed the review, collected the literature data and prepared the manuscript.

\section{Declaration of conflicting interests}

The author declared no potential conflicts of interest with respect to the research, authorship, and/or publication of this article. 


\section{REFERENCES}

1. Ritchie H, Roser M: Meat and seafood production and consumption. [https:// ourworldindata.org/meat-and-seafood-production-consumption]

2. FAO: Feeding the world. [http://www.fao.org/3/i3107e/i3107e03.pdf]

3. Carlsen E, Giwercman A, Keiding N, Skakkebeak N: Evidence for decreasing quality of semen during past 50 years. Brit Med J 1992, 205:609-613.

4. Aho, Koivisto AM, Tammela TL, Auvinen A: Is the incidence of hypospadias increasing? Analysis of Finnish hospital discharge data 1970-1994. Environ Health Perspect 2000, 108:463-465.

5. Carmichael SL, Shaw GM, Nelson V, Selvin S, Torfs CP, Curry CJ: Hypospadias in California: Trends and descriptive epidemiology. Epidemiology 2003, 14:701-706.

6. Paulozzi LJ: International trends in rates of hypospadias and cryptorchidism. Environ Health Perspect 1999, 107:297-302.

7. Ganmaa D, Sato A: The possible role of female sex hormones in milk from pregnant cows in the development of breast, ovarian and corpus uteri cancers. Medical Hyptheses 2005, 65:1028-1037.

8. Sharpe RM, Skakkebeak NE: Are estrogens involved in falling sperm counts and disorders of the male reproductive tract? Lancet 1993, 341:1392-1395.

9. Courant F, Antignac J, Laille J, Monteau F, Andre F, Le Bizec B: Exposure assesment of preburtal children to steroid endocrine disruptors. Determination of steroid hormones in milk, egg and meat samples. J Agric Food Chem 2008, 56:3176-3184.

10. Coady K, Mathiessen P, Zahner NM, Staveley J, Caldwell DJ, Levine SL, Gray jr LE, Borgert CJ: Endocrine disruption: where are we with hazard and risk assessment? Peer J Preprints 2016, 4:e2580v1.

11. CRL Guidance paper (7 December 2007): CRLs view on state of the art analytical methods for national residue control plans. [https://www.rivm.nl/bibliotheek/digitaaldepot/ crlguidance2007.pdf]

12. US DHHS-FDA (Department of Health and Human Services - Food and Drug Administration): Guidance for industry. General principles for evaluating the human food safety of new animal drugs used in food-producing animals. [https://www.fda.gov/ downloads/AnimalVeterinary/GuidanceComplianceEnforcement/GuidanceforIndustry/ UCM052180.pdf]

13. Macrina AL, Ott TL, Roberts RF, Kensinger RS: Estrone and estrone sulfate concentrations in milk and milk fractions. J Acad Nutr Dietet 2012, 112:1088-1093.

14. Leon-Olea M, Martyniuk CJ, Orlando EF, Ottinger MA, Rosenfeld CS, Wolstenholme JT, Trudeau VL: Current concepts in neuroendocrine disruption. General and Comparative Endocrinology 2014, 203:158-173.

15. Fortier A, Trasler J: Potential epigenetic consequences associated with assisted reproduction. In: Epigenitc and human reproduction. Heidelberg, Germany: Springer; 2011, 3-18.

16. Drobnis EZ, Nangia AK: Male reproductive functions disrupted by pharmacological agents. Advan Experiment Med Biol 2017, 1034-24.

17. Andersson AM, Skakkebaek NE: Exposure to exogenous estrogens in food: possible impact on human development and health. Eur J Endocrinol 1999, 140:477-485.

18. Schug TT, Janesick A, Blumberg B, Heindel JJ: Endocrine disrupting chemicals and disease susceptibility. J Steroid Biochem Molec Biol 2011, 127:204-215. 
19. Torfadottir JE, Steingrimsdottir L, Mucci L, Aspelund T, Kasperzyk JL, Olafsson O, Fall K, Tryggvadottir L, Harris TB, Launer L, Jonsson E, Tulinius H, Stampfer M, Adami HO, Gudnason V, Valdimarsdottir UA: Milk intake in early life and risk of advanced prostate cancer. Am J Epidemiol 2012, 175:144-153.

20. Key TJA, Pike MC: The dose-effect relationship between 'unopposed' estrogens and mitotic rate: its general role in explaning and predicting endometrial cancer risk. Brit JCancer 1988, 57:205-212.

21. Dickson RB, Lippman ME: Estrogenic regulation of growth and polypeptide growth factor secretion in human breast carcinoma. Endocr Rev 1987, 8:29-43.

22. Braekevelt EB, Lau P, Tague B, Popovic S, Tittlemier SA. Effect of cooking on concentrations of $\beta$-estradiol and metabolites in model matrices and beef. J Agric Food Chem 2011, 59:915-920.

23. Snoj T, Zuzek MC, Cebulj-Kadunc N, Majdic G: Short communication: Heat treatment and souring do not affect milk estrone and 17b-estradiol concentrations. J Dairy Sci 2018, 101:61-65.

24. Hartmann S, Lacorn M, Steinhart H: Natural occurrence of steroid hormones in food. Food Chem 1998, 62:7-20.

25. Zhou H, Qin LQ, Ma DF, Wang Y, Wang PY: Uterotrophic effects of cow milk in immature ovariectomized Sprague-Dawley rats. Environment Health Prevent Med 2010, 15:162-168.

26. Gaiani R, Chiesa F, Mattioli M, Nanneti G, Galeati G: Androstenedione and testosterone concentrations in plasma and milk of cow throughout pregnancy. J Reprod Fertil 1984, 70:55-90.

27. Heap RB, Hamon M: Oestrone sulphate in milk as an indicator of a viable conceptus in cows. Br Vet J, 135:355-363.

28. Malekinejad H, Scherpenisse P, Bergerff AA: Naturaly occurring estrogens in processed milk and in raw milk (from gestated cows). J Agric Food Chem 2006, 54:9785-9791.

29. Pape-Zambito DA, Magliaro AL, Kensinger RS: 17b-estradiol and estrone concentrations in plasma and milk during bovine pregnancy. J Dairy Sci 2008, 91:127-135.

30. Farlow DW, Xu X, Veenstra TD: Comparison of estrone and 17b-estradiol levels in commercial goat and cow milk. J Dairy Sci 2012, 95:1699-1708.

31. Macdonald IA, Bokkenheuser VD, Winter J, McLernon AM, Mosbach EH: Degradation of steroids in the human gut. J Lip Res 1983, 24:675-700.

32. Parodi PW: Impact of cow's milk estrogen on cancer risk. Int Dairy J 2012, 22:3-14.

33. US DHHS-FDA (Department of Health and Human Services - Food and Drug Administration): Steroid hormone implants used for growth in food-producing animals. [https://www.fda.gov/animal-veterinary/product-safety-information/steroid-hormoneimplants-used-growth-food-producing-animals]

34. US DHHS-FDA (Department of Health and Human Services - Food and Drug Administration): Report on the Food and Drug Administration's review of the Safety of recombinant bovine somatotropin. [https://www.fda.gov/animal-veterinary/productsafety-information/report-food-and-drug-administrations-review-safety-recombinantbovine-somatotropin]

35. Dohoo IR, DesCoteaux L, Leslie K, Fredeen A, Shewfelt W, Preston A, Dowling P: A meta-analysis review of the effects of recombinant bovine somatotropin. Can J Vet Res 2003, 67:252-264. 
36. Maldonado-Cerceles AB, Minguez-Alacon L, Mendiola J, Vioque J, Jorgensen N, Arense Gonzalo JJ, Tores-Cantero AM, Chavarro J: Meat intake in relation to semen quality and reproductive hormone levels among young men in Spain. Br J Nutr 2018, 121:1-10.

37. Afeiche MC, Williams PL, Gaskins AJ, Mendiola J, Jorgensen N, Swan SH, Chavarro JE: Meat intake and reproductive parameters among young men. Epidemiology 2014, 25:323330.

38. Xia W, Chiu YH, Williams PL, Gaskins AJ, Toth TL, Tanrikut C, Hauser R, Chavarro JE: Men's meat intake and treatment outcomes among couples undergoing assisted reproduction. Fertil Steril 2015, 104:972-979.

39. Swan SH, Liu F, Overstreet JW, Brazil C, Skakkebeak NE: Semen quality of fertile US males in relation to their mothers' beef consumption during pregnancy. Hum Reprod 2007, 22:1497-1502.

40. Afeiche MC, Bridges ND, Williams PL, Gaskins AJ, Tanrikut C, Petrozza JC, Hauser R, Chavarro JE: Dairy intake and semen quality among men attending a fertility clinic. Fertil Steril 2014, 101:1280-1287.

41. Afeiche M, Williams PL, Mendiola J, Gaskins AJ, Jorgensen N, Swan SH, Chavarro JE: Dairy food intake in relation to semen quality and reproductive hormone levels among physically active men. Hum Reprod 2013, 28:2265-2275.

42. Dizavi A, Eini-Zinab H, Hosseini J, Omidvar N, Hosseini MA: Relationship between dairy product consumption and oligospermia; a case-control study. Men Health J 2018, 2:1-7.

43. Xia W, Chiu YH, Afeiche MC, Williams PL, Ford JB, Tanrikut C, Souter I, Hauser R, Chavarro JE: Impact of men's dairy intake on assisted reproductive technology outcomes among couples attending a fertility clinic. Andrology 2016, 4:277-283.

44. Cross AJ, Leitzmann MF, Gail MH, Hollenbeck AR, Schatzkin A, Sinha R: A prospective study of red and processed meat intake in relation to cancer risk. PLoS Med 2007, 4:e325.

45. Lijinsky W: N-Nitroso compounds in the diet. Mutat Res 1999, 443:129-138.

46. Ohgaki H, Hasegawa H, Kato T, Suenaga M, Sato S, Takayama S, Suqimura T: Carcinogenicities in mice and rats of IQ, MeIQ, and MeIQx. Princess Takamatsu Symp 1985, 16:97-105.

47. Bandera EV, Kushi LH, Moore DF, Gifkins DM, McCullough ML: Consumption of animal foods and endometrial cancer risk: a systematic literature review and meta-analysis. Cancer Causes Control 2007,18:967-988.

48. Dagnelie PC, Schuurman AG, Goldbohm RA, Van den Brandt PA: Diet, anthropometric measures and prostate cancer risk: a review of prospective cohort and intervention studies. BJU Int 2004, 93:1139-1150.

49. WHO: Agents classfied by the IARC monographs, volumes 1-123. [https://monographs. iarc.fr/agents-classified-by-the-iarc/]

50. Dong JY, Zhang L, He K, Qin LQ: Dairy consumption and risk of breast cancer: a metaanalysis of prospective cohort studies. Breast Cancer Res Treat 2011, 127:23-31.

51. Zang J, Shen M, Du S, Chen T, Zou S: The association between dairy intake and breast cancer in Western and Asian populations: a systematic review and meta-analysis. J Breast Cancer 2015, 18 313-322.

52. Moorman PG, Terry PD: Consumption of dairy products and the risk of breast cancer: a review of the literature. Am J of Clin Nutr, 2004, 80:5-14.

53. Missmer SA, Smith-Warner SA, Spiegelman D, Yaun SS, Adami HO, Beeson WL van den Brandt PA, Fraser GE, Freudenheim JL, Goldbohm RA, Graham S, Kushi LH, Miller AB, 
Potter JD, Rohan TE, Speizer FE, Toniolo P, Willett WC, Wolk A, Zeleniuch-Jacquotte A, Hunter DJ: Meat and dairy food consumption and breast camcer: a pooled analysis of cohort studies. Int J Epidemiol 2002, 31:78-85.

54. Davies TW, Palmer CR, Ruja E, Lipscombe JM: Adolescent milk, dairy product and fruit consumption and testicular cancer. Brit J Cancer 1996, 74:657-660.

55. Aune D, Navarro Rosenblatt DA, Chan DS, Vieira AR, Vieira R, Greenwood DC, Vatten LJ, Norat T: Dairy products, calcium, and prostate cancer risk: a systematic review and meta-analysis of cohort studies. Am J Clin Nutr 2015, 101:87-117.

56. Andersson SO, Baron J, Wolk A, Lindgren C, Bergström R, Adami HO: Early life risk factors for prostate cancer: a population-based case-control study in Sweden. Cancer Epidemiol Biomark Prevent 1995, 4:187-192.

57. Aune D, De Stefani E, Ronco AL, Boffetta P, Deneo-Pellegrini H, Acosta G, Mendilaharsu M: Egg consumption and the risk of cancer: a multisite case-control study in Uruguay. Asian Pac J Cancer Prev 2009, 10:869-876.

58. Zamora-Ros R, Cayssials V, Cleries R, Redondo ML, Sanchez MJ, Rodriguez-Barranco M5, Sanchez-Cruz JJ, Mokoroa O, Gil L, Amiano P, Navarro C, Chirlaque MD, Huerta JM, Barricarte A, Ardanaz E, Moreno-Iribas C, Agudo A: Moderate egg consumption and allcause and specific-cause mortality in the Spanish European Prospective into Cancer and Nutrition (EPIC-Spain) study. Eur J Nutr 2018, doi: 10.1007/s00394-018-1754-6.

59. Fernandez E, Chatenoud L, La Vecchia C, Negri E, Franceschi S: Fish consumption and cancer risk. Am J Clin Nutr 1999, 70:85-90.

60. Santarelli RL, Vendeuvre JC, Naud N, Tache S, Gueraud F, Viau M, Genot C, Corpet DE, Pierre FHF: Meat processing ant colon carcinogenesis: cooked, nitrite-treated, and oxidized high-heme cured meat promoted mucin-depleted foci in rats. Cancer Prev Res (Phila Pa) 2010, 3:852-864.

61. Parnaud G, Peiffer G, Tache S, Corpet DE: Effect of meat (beef, chicken and bacon) on rat colon carcinogenesis. Nutr Cancer 1998, 32:165-173.

62. Ganmaa D, Tezuka H, Enkhmaa D, Hoshi K, Sato A: Commercial cows' milk has uterotrophic activity on the uteri of young ovariectomized rats and immature rats. Int J Cancer 2005, 118: 2363-2365.

63. Li XM, Ganmaa D, Qin LQ, Sato A: Testing potential effects of environmental endocrine disruptors in cow milk on reproductive index in female rats. Biomed Environ Sci 2005, 18:307-313.

64. Ganmaa D, Qin LQ, Wang PY, Tezuka H, Teramoto S, Sato A: A two-generation reproduction study to assess the effects of cows' milk on reproductive development in male and female rats. Fertil Steril 2004, 82:1106-1114.

65. Grgurevič N, Koračin J, Majdič G, Snoj T: Effect of dietary estrogens from bovine milk on blood hormone levels and reproductive organs in mice. J Dairy Sci 2016, 99:6005-6013.

66. Qin LQ, Xu JY, Wang PY, Ganmaa D, Li J, Wang J, Kaneko T, Hoshi K, Shirai T, Sato A: Low-fat milk promotes the development of 7,12-dimethylbenz(A)anthracene (DMBA)induced mammary tumors in rats. Int J Cancer 2004, 110:491-496.

67. Genkinger JM, Koushik A: Meat consumption and cancer risk. PLoS Med 2007, 4:e345.

68. Panth N, Gavarkovs A, Tamez M, Mattei J: The Influence of diet on fertility and the implications for public health nutrition in the United States. Front Public Health 2018, $6: 211$. 
69. Davoodi H, Esmaeili S, Mortazavian AM: Effects of milk and milk products consumption on cancer: a review. Compr Rev Food Sci Food Saf 2013, 12:249-264.

70. Snoj T, Majdič G: Estrogens in consumer milk: is there a risk to human reproductive health? Eur J Endocrinol 2018, 179:275-286.

71. Malekinejad H, Rezabakhsh A: Hormones in dairy foods and their impact on public ealth - A narrative review article. Iran J Public Health. 2015, 44:742-758.

72. Keum N, Lee DH, Marchand N, Oh H, Liu H, Aune D, Greenwood DC, Giovannucci EL: Egg intake and cancers of the breast, ovary and prostate: a dose-response meta-analysis of prospective observational studies. Br J Nutr 2015, 114:1099-1107.

73. Snoj T, Majdič G, Kobal S, Žužek M, Čebulj-Kadunc N: Estrone, 17b-estradiol and progesterone concentrations in processed milk with different fat content. Veterinarski Glasnik 2017, 71(1):35-43. doi: 10.2298/VETGL170324006S

\title{
HORMONI U HRANI KAO POTENCIJALNI RIZIK ZA REPRODUKTIVNE I ZDRAVSTVENE POREMEĆAJE KOD LJUDI
}

\author{
SNOJ Tomaž
}

U proteklih 60 godina, potrošnja mleka, mesa i jaja po glavi stanovnika u svetu je porasla dva, tri odnosno pet puta. $U$ istom vremenskom periodu, obavljeno je nekoliko studija koje ukazuju na pad kvaliteta ejakulata i povećanu pojavu kriptorhizma, hipospadije i nekih karcinoma koji su povezani sa hormonskim statusom (testisi, prostata, mlečna žlezda) kod ljudi. Mogući uzrok ovih poremećaja je povećana ekspozicija egzogenim hormonima iz hrane životinjskog porekla. Smatra se da hormoni u hrani utiču na endokrini sistem i ćelije dajući signale i remeteći homeostazu kod ljudi koji konzumiraju takvu vrstu hrane. S obzirom na garancije koje se odnose na bezbednost hrane, a koje su deo veterinarskog nadzora, procena rizika prisustva hormona u hrani, koji su potencijalne neželjene supstancije, predstavlja izazov za veterinarsku službu. Obavljene su brojne grupne i epizootiološke studije kao i meta-analize u odnosu na ustanovljavanje povezanosti između konzumiranja hrane animalnog porekla sa jedne strane i pojave određenih oboljenja i poremećaja zdravlja sa druge. Pored toga, obavljeno je nekoliko studija u kojima su bile životinje kao model, sa ciljem da se objasne mehanizmi neželjenih efekata egzohormona. Pošto su dobijeni kontradiktorni rezultati, ipak ne mogu da se donesu nedvosmisleni zaključci u odnosu na neželjene efekte egzohormona na ljude. Iz tog razloga, da bi se potvrdila ili opovrgla uloga egzogenih hormona na zdravstveno stanje i poremećaj zdravlja ljudi, neophodno je da se obave dodatna istraživanja na životinjama, a u odnosu na dugotrajni tretman egzogenim hormonima primenom sveobuhvatnih endokrinoloških, toksikoloških i epidemioloških 
ispitivanja. Uz to, nije poznato koji su to dodatni efekti dugotrajne ekspozicije kombinacijama većeg broja egzogenih komponenti, kao što su to supstance koje zagađuju životnu sredinu i dijetetski hormonskii proizvodi, što treba da bude predmet dodatnih ispitivanja. 